\title{
Desalination of Ground Water: Earth Science Perspectives
}

Desalination is a water-treatment process that removes salts from water. Concerns about the sustainability of freshwater supplies, as well as rapid advances in membrane and other watertreatment technologies, are fostering a renewed interest in desalination as a partial solution to increased water demand. It is projected that more than 70 billion dollars will be spent worldwide over the next 20 years to design and build new desalination plants and facilities (Sandia National Laboratories, 2002).

\section{"By 2020, desalination and water} purification technologies will contribute significantly to ensuring a safe, sustainable, affordable, and adequate water supply for our nation."

Guiding vision for Desalination and Water Purification Technology Roadmap prepared by the U.S. Bureau of Reclamation and Sandia National Laboratories (2003).

Desalination presents the possibility of providing freshwater not only from the ocean, but also from saline ground water. The potential importance of desalination is exemplified, for example, by New Mexico where approximately 75 percent of ground water is too saline for most uses without treatment (Reynolds, 1962, p. 91). Earth-science issues related to desalination of ground water include the distribution of saline groundwater resources, the chemical characteristics and suitability of ground water for desalination, effects of extraction of saline ground water on connected freshwater resources, and disposal of residual products. These issues are discussed by posing a series of basic questions.

\section{What is saline ground water?}

Salinity is a term used to describe the amount of salt in a given water sample. It usually is referred to in terms of total dissolved solids (TDS) and is measured

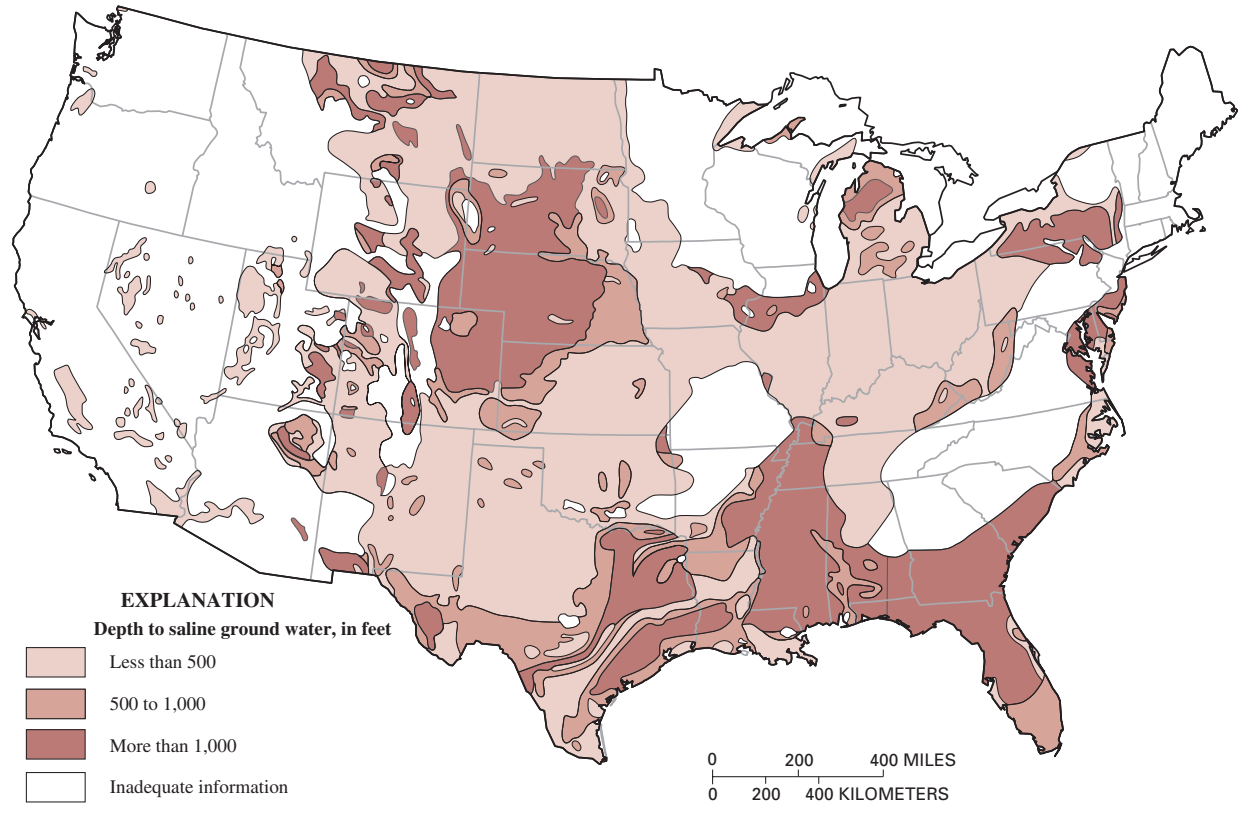

Figure 1. Depth to saline ground water in the United States (generalized from Feth and others, 1965)

in milligrams of solids per liter $(\mathrm{mg} / \mathrm{L})$. Water with a TDS concentration greater than $1,000 \mathrm{mg} / \mathrm{L}$ commonly is considered saline. This somewhat arbitrary upper limit of freshwater is based on the suitability of water for human consumption. Although water with TDS greater than $1,000 \mathrm{mg} / \mathrm{L}$ is used for domestic supply in areas where water of lower TDS content is not available, water containing more than $3,000 \mathrm{mg} / \mathrm{L}$ is generally too salty to drink. The U.S. Environmental Protection Agency has established a guideline (secondary maximum contaminant level) of $500 \mathrm{mg} / \mathrm{L}$ for dissolved solids. Ground water with salinity greater than seawater (about $35,000 \mathrm{mg} / \mathrm{L}$ ) is referred to as brine.

\section{Where is saline ground water located?}

Little is known about the hydrogeology of the parts of most aquifers that contain saline water compared to the parts that contain freshwater, because the need to utilize saline ground water has been limited. Most ground-water resource evaluations have been devoted to establishing the extent and properties of freshwater aquifers, whereas evaluations of saline water-bearing units have been mostly devoted to determining the effects on freshwater movement.

Much of the work to characterize saline ground-water resources in the United States was done in the 1950s, 1960s, and 1970s. Surveys of saline water resources of several States (for example, Winslow and Kister, 1956), and of selected areas within States (for example, Hood, 1963), were published in the late 1950s and early 1960s. Krieger and others (1957) undertook a preliminary survey of the saline water resources of the United States during this period. Later, Feth and others (1965) prepared a generalized map of the depth to saline ground water for the conterminous United States (fig. 1). This map provides 
a preliminary perspective on the location of saline ground-water resources, but provides limited information about critical factors required to understand the development potential of the resources such as aquifer hydraulic conductivity and well yields.

Reports published in U.S. Geological Survey (USGS) Professional Paper Series 813 in the 1970 s present very generalized analyses of ground-water resources within each of the 21 Water Resources Regions of the United States. Many of these reports contain a short summary statement about the saline water resources of a region, including use of saline aquifers as a source of treatable water, place to store freshwater, or place to dispose of liquid waste. Subsequently, the USGS developed quantitative assessments of 25 of the Nation's most important regional aquifer systems, as part of the Regional Aquifer-System Analysis (RASA) Program (USGS Professional Paper Series 1400-1425). Reports on the geochemistry of some of these aquifer systems and the Ground-Water Atlas of the United States (Miller, 2000) produced as a part of the RASA Program contain maps and data about dissolved-solids and specific ion concentrations for selected areas (fig. 2).

Subsurface data on water chemistry and hydrology typically are restricted to near-surface, freshwater aquifers and to sediments containing deeper, commonly highly saline, oil-field water. Few wells are located in intermediate areas

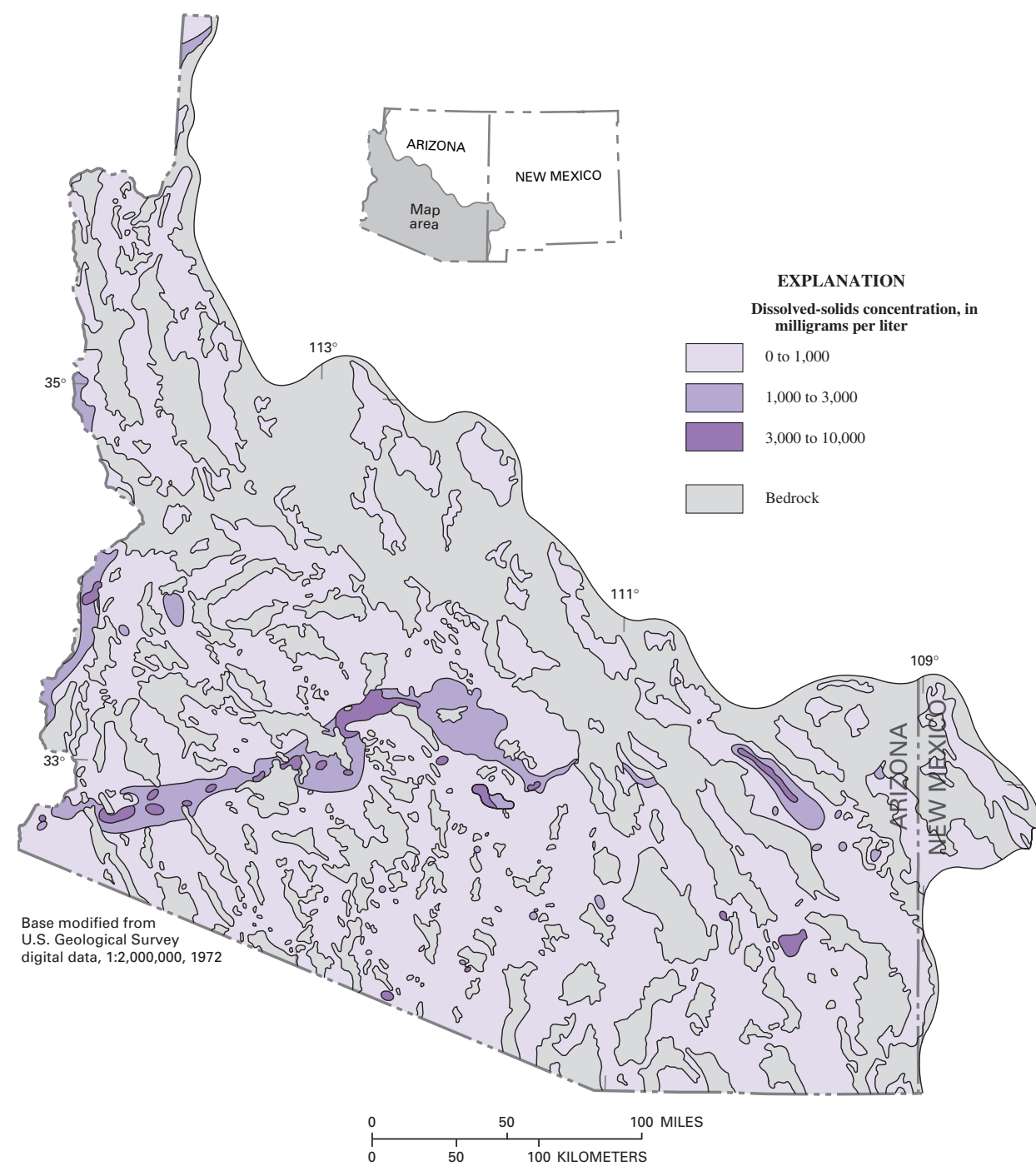

Figure 2. Dissolved-solids concentrations in basin-fill aquifers in Arizona and New Mexico are typically less than $1,000 \mathrm{mg} / \mathrm{L}$, but can be much higher. Areas of higher concentrations include low parts of some basins where dissolved solids are concentrated by evapotranspiration from shallow ground water, basins with smaller fluxes of water naturally circulating through the ground-water system, near deposits of saline minerals, and in some areas of salt buildup from intensive irrigation. (modified from Kister, 1973; Robson and Banta, 1995) that might be of interest for saline-water development. Thus, surface and subsurface geophysical techniques to supplement information from wells may prove useful tools for saline water-resource evaluation.

\section{How do we characterize the chemistry of saline ground water with respect to suitability for desalination?}

The dissolved-solids concentration of saline ground waters typically is less than that of seawater. Saline ground water, however, has a greater tendency than seawater to precipitate sulfate (for example, gypsum), carbonate (for example, calcite), and silicate scales (fig. 3). The tendency of saline ground water to form scale is important to its suitability for use in desalination. Saline ground water also may contain some constituents, such as arsenic, elevated radioactivity, and dissolved organic material, at greater concentrations than in seawater. Although a relatively large body of information exists on the chemical behavior of solutes within desalination systems, relatively little research has been undertaken on the chemical suitability of water from various aquifers as sources for desalination.

\section{What are the effects of using saline ground waters on fresh- water resources and the environ- ment?}

Although one might at first consider saline ground water as a "new" source of water, the parts of aquifers containing saline water commonly are connected hydraulically to parts of the same aquifer or aquifer system that contain freshwater. Thus, development of one resource affects the other, as well as potentially affecting the flow and quality of surface-water bodies connected to the ground-water system. These effects may extend over many years or decades. Techniques are needed to predict the effects of saline ground-water development in three dimensions and with time. Variable density numerical models have been used successfully to simulate the subsurface occurrence and movement of saltwater in coastal environments in many locations. The use of these models to quantify the movement of inland saline water resources would aid in understand- 


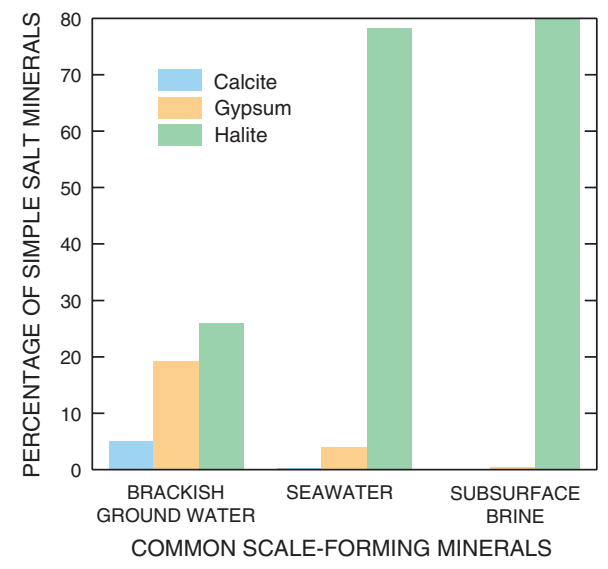

Figure 3. Normative analysis (Bodine and Jones, 1986) can be useful in characterizing the chemical composition of saline water. Calculated simple salt norms demonstrate the preferred association of cations and anions based on relative solubility of evaporite minerals. These are derived from the equilibrium salt assemblages obtained on complete evaporation of a water sample under ambient conditions. The resulting cation-anion associations (simple salts) readily show the relative abundance of principal scale-forming mineral phases. This is illustrated graphically by comparison of simple salt mineral percentages calculated from analyses of brackish ground water, seawater, and subsurface brine (data from Wood and Jones, 1990). In this way, a quick evaluation can be made of the magnitude and type of potential scaling problems for a given saline water resource.

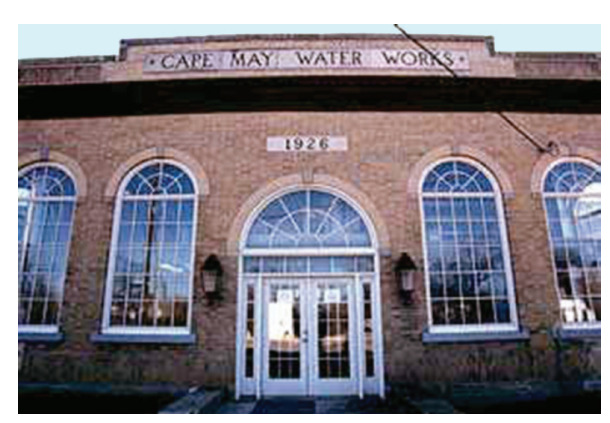

ing the impacts of utilizing saline water resources for desalination.

Disposal of the volumes of brine produced as a residual product of desalination is a primary environmental issue associated with desalination. Residual products from desalination of seawater are pumped to the sea. The expense of geologic disposal of residual products from inland saline ground water is a major factor that affects the costeffectiveness of ground-water desalination. Disposal of residual products of desalination requires careful consideration of their chemical composition. For example, disposal in deeper (higher temperature) saline aquifers may lead to precipitation of minerals, including calcite and gypsum that have lower solubility at higher temperatures (Kharaka and others, 1997). Underground injection of saline water currently is done in the United States to dispose of oil-field brines.

\section{Are there other sources of treat- able ground water?}

Other sources of ground water may be amenable to desalination. These possibilities, for which research continues, include treating water co-produced with oil and conventional natural gas (Kharaka and others, 1999) and water co-produced with coal-bed methane (Rice and Nuccio, 2000). Many oil- and gas-producing for-

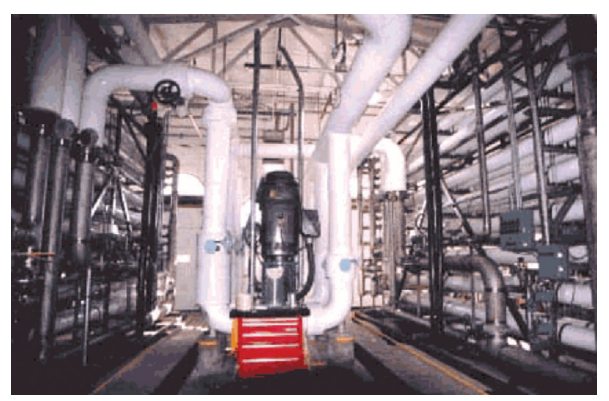

(Left photograph) A desalination plant for the City of Cape May, New Jersey, was built inside the brick building of the former Cape May Water Works. (Right photograph) The automated desalination plant can produce from 750,000 to 2 million gallons of water per day. (Photos: Jennifer Kopp, courtesy of CapeMay.com)

Saltwater contamination has forced the closure of water-supply wells for the City of Cape May, New Jersey, and caused concerns about the future sustainability of ground water. Long-term monitoring of the resource and a numerical ground-water model of the aquifer system of the Cape May Peninsula were key elements to help engineers design an approach to combine desalination of brackish ground water at some wells and reduce pumping at others to stabilize the saltwater front (Lacombe and Carleton, 2002; Galloway and others, 2003).

mations have associated water that is only slightly saline (less than 10,000 mg/L), notably in the intermountain basins of the western United States. Coal-bed methane water in the Powder River Basin of Wyoming is generally less than $3,000 \mathrm{mg} / \mathrm{L}$ TDS. The likely presence of organic compounds in this water complicates treatment.

\section{Summary Remarks}

Desalinated ground water potentially represents an increasing component of the Nation's water supply; however, relatively little is known about saline ground-water resources. An improved knowledge base is needed to better define their distribution and physical and chemical characteristics; to predict the effects of saline-water extraction on the environment; and to support proper disposal of waste products. This information is needed to support economic development of the resources, and to provide a scientific basis for regulatory and policy issues.

\section{References Cited}

Bodine, M.W., Jr., and Jones, B.F., 1986, The salt norm: A quantitative chemical-mineralogical characterization of natural water: U.S. Geological Survey Water-Resources Investigations Report 86-4086, 130 p.

Feth, J.H., and others, 1965, Preliminary map of the conterminous United States showing depth to and quality of shallowest ground water containing more than 1,000 parts per million dissolved solids: U.S. Geological Survey Hydrologic Investigations Atlas HA-199.

Galloway, D.L., Alley, W.M., Barlow, P.M., Reilly, T.E., and Tucci, P., 2003, Evolving issues and practices in managing ground-water resources-Case studies on the role of science: U.S. Geological Survey Circular 1247, 73 p.

Hood, J.W., 1963, Saline ground water in the Roswell Basin, Chaves and Eddy Counties, New Mexico, 1958-59: U.S. Geological Survey Water-Supply Paper 1539-M, 46 p. 
Kharaka, Y.K., Ambats, G., Thordsen, J.J., and Evans, W.C., 1997, Deep-well injections of brine from Paradox Valley, Colorado: Potential major precipitation problems remediated by nanofiltration: Water Resources Research, v. 33, p. 1013-1020.

Kharaka, Y.K., Leong, L.Y.C., Doran, G., and Breit, G.N., 1999, Can produced water be reclaimed?: Experience with the Placerita oil field, California, in Sublette, K.L., ed., Environmental Issues in Petroleum Exploration, Production and Refining: Proceedings 5th IPEC meeting, October, 1998, CD-ROM format.

Kister, L.R., 1973, Quality of ground water in the lower Colorado River region, Arizona, Nevada, New Mexico, and Utah: U.S. Geological Survey Hydrologic Investigations Atlas HA-478, 2 sheets.

Krieger, R.A., Hatchett, J.L., and Poole, J.L., 1957, Preliminary survey of the saline-resources of the United States: U.S. Geological Survey Water-Supply Paper 1374, 172 p.
Lacombe, P.J., and Carleton, G.B., 2002, Hydrogeologic framework, availability of water supplies, and saltwater intrusion, Cape May County, New Jersey: U.S. Geological Survey Water-Resources Investigations Report 01-4246, 151 p.

Miller, J.A., 2000, Ground-water atlas of the United States: U.S. Geological Survey, 13 chapters. Available on the Internet at http://capp.water.usgs.gov/ gwa/.

Reynolds, S.E., 1962, Twenty-fifth biennial report of the State Engineer of New Mexico: The Valliant Company, Albuquerque, New Mexico, 193 p.

Rice, C.A., and Nuccio, V., 2000, Water produced with coal-bed methane: U.S. Geological Survey Fact Sheet FS-156-00, 2 p.

Robson, S.G., and Banta, E.R., 1995, Ground-water atlas of the United States, segment 2, Arizona, Colorado, New Mexico, and Utah: U.S. Geological Survey Hydrologic Investigations Atlas HA-730C, 32 p.
Sandia National Laboratories, 2002, Tularosa basin national desalination research facility study: U.S. Bureau of Reclamation Report to Congress, 34 p.

U.S. Bureau of Reclamation and Sandia National Laboratories, 2003, Desalination and water purification technology roadmap: U.S. Bureau of Reclamation, Desalination and Water Purification Research and Development Report \#95, Denver, Colorado, 61 p.

Winslow, A.G., and Kister, L.R., 1956, Saline-water resources of Texas: U.S. Geological Survey Water-Supply Paper $1365,105 \mathrm{p}$.

Wood, W.W., and Jones, B.F., 1990, Origin of solutes in saline lakes and springs on the southern High Plains of Texas and New Mexico: In T.C. Gustavson, ed., Geologic framework and regional hydrology: Upper Cenozoic Blackwater Draw and Ogallala Formations, Great Plains: The University of Texas at Austin, Bureau of Economic Geology Report, p. 193-208.

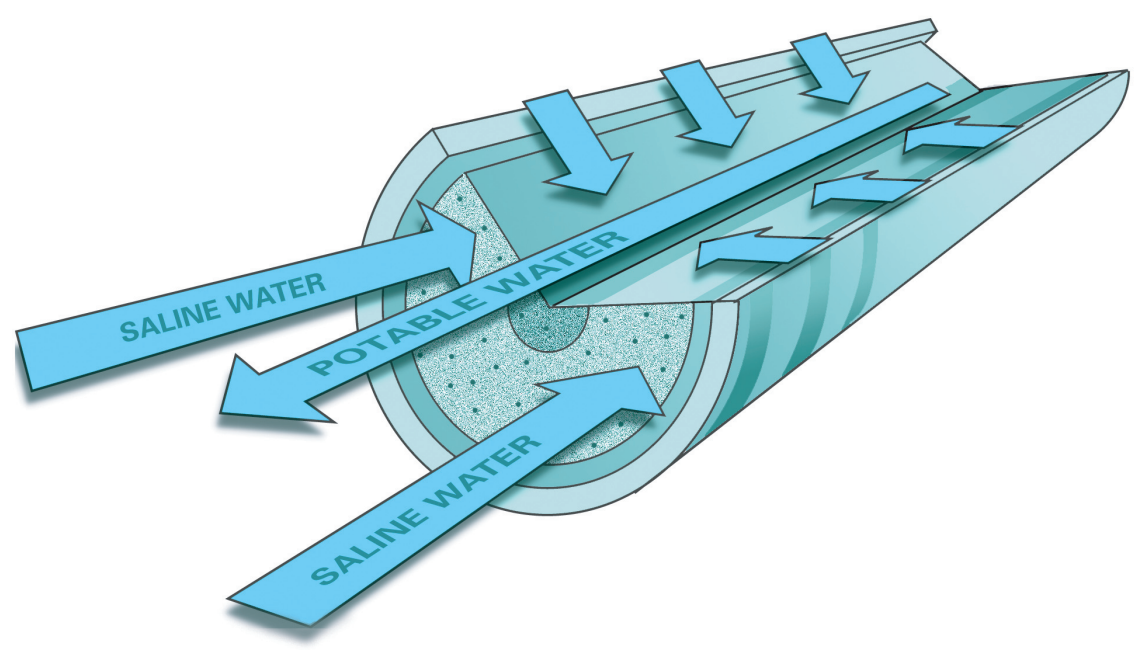

—William M. Alley

For more information on ground-water resource issues, please contact:

Office of Ground Water U.S. Geological Survey 411 National Center 12201 Sunrise Valley Drive Reston, VA 20192 (703) 648-5001

Filtration

Membrane

Element 